\title{
ADSORPTION OF REMAZOL BRILLIANT VIOLET ONTO CHITOSAN 10B IN AQUEOUS SOLUTION: KINETICS, EQUILIBRIUM AND THERMODYNAMICS STUDIES
}

\author{
SUBARNA KARMAKER, AMLAN JYOTI NAG and TAPAN KUMAR SAHA* \\ Department of Chemistry, Jahangirnagar University, Savar, Dhaka-1342, Bangladesh \\ ×Corresponding author: T. K. Saha, tksaha_ju@yahoo.com
}

Received August 15, 2018

The adsorption characteristics of Remazol Brilliant Violet (RBV) dye onto chitosan 10B were investigated in aqueous solutions as a function of solution $\mathrm{pH}$, dye concentration, ionic strength and temperature, respectively. The adsorption kinetics data obtained from various batch experiments were analyzed by using pseudo-first- and pseudo-second-order, as well as Elovich and intraparticle diffusion kinetic models. The results exhibited that the sorption process obeys pseudo-second order kinetics, whereas intraparticle diffusion is the rate determining step. The equilibrium adsorption isotherm data are fitted better by the Langmuir model rather than by the Freundlich, Temkin and DubininRadushkevich models. Moreover, the mean adsorption energy $(E)$ from the Dubinin-Radushkevich isotherm and the activation energy $\left(E_{\mathrm{a}}\right)$ from the Arrhenius equation indicate that the RBV adsorption onto chitosan 10B is a physisorption process. Thermodynamic parameters, such as the changes in free energy $(\Delta G)$, enthalpy $(\Delta H)$ and entropy $(\Delta S)$, suggest that the RBV dye adsorption onto chitosan 10B in aqueous solution is spontaneous and endothermic in nature. Desorption tests were carried out in a $\mathrm{NaOH}$ solution $(\mathrm{pH} 12.5)$ and the chitosan flakes were found to be reusable.

Keywords: adsorption, kinetics, equilibrium, thermodynamics, chitosan, azo dyes

\section{INTRODUCTION}

A large number of anionic azo dyes are widely used in textile dyeing, paper printing and manufacture of pharmaceutical drugs and toys. This group of dyes dominates the world-wide market of dyestuffs with a share of about $70 \%{ }^{1}$ They are less susceptible to oxidative catabolism and generally non-biodegradable. Only a few can be degraded microbiologically under anaerobic conditions, but in most cases, with the production of carcinogenic amines and mutagens. ${ }^{2}$

Conventional processes, such as adsorption, oxidation-ozonation, coagulation, coagulationflocculation, and biological methods are adopted for removing azo dyes. Adsorption methods in solution systems play a vital role in many areas of practical environmental technology, which are mainly used in waste water treatment, due to several advantages, such as high efficiency, simple operation and easy recovery/reuse of the adsorbent. ${ }^{3}$ Many types of adsorbent materials, such as clay minerals, ${ }^{4-6}$ perlite, ${ }^{7}$ biomaterials ${ }^{8,9}$ activated carbons ${ }^{10,11}$ and industrial solid wastes, ${ }^{12}$ have been tested for the removal of azo dyes from aqueous solution. Activated carbon is extensively used as an adsorbent due to its high degree of effectiveness. However, its use is limited because of its high cost.

This has led many researchers to search for low cost and locally available adsorbents, so that the process becomes economically feasible. In recent years, biomass has been accepted as an appropriate low-cost adsorbent for the removal of dyes from aqueous solution. Many types of natural and modified biomass, such as biochars, ${ }^{13}$ mango leaves, ${ }^{14}$ Daucus carota ${ }^{15}$ Irvingia gabonenses ${ }^{16}$ agricultural by-products, ${ }^{17}$ chitin, ${ }^{18}$ chitosan $^{19-23}$ and functionalized chitosan, ${ }^{24-26}$ have shown promising results in dye adsorption applications. However, related reports on utilizing chitosan to remove Remazol Brilliant Violet (RBV; Fig. 1a) azo dye from aqueous solution are relatively scarce. In this study, chitosan 10B (Fig. 1b) has been selected as an adsorbent to remove RBV from aqueous solution. 
Chitosan is simply obtained from chitin by deacetylating its acetoamide groups with a strong alkaline solution. Chitin is generally found in wastes from the seafood processing industry, mainly shells of crabs, shrimp, prawns and krill. Shrimp shell waste is generated in huge amounts by the seafood processing industries from Bangladesh (more than 30,000 tons per year). ${ }^{27}$ This waste is low-cost, available in abundance and suitable for producing chitin polymer. Consequently, the high proportions of amino and hydroxyl functions in chitosan make it very useful for the adsorption and removal of several dyes from industrial wastewater.

The objective of the present study has been to assess the ability of chitosan 10B to adsorb the RBV azo dye from aqueous solution and to optimize the conditions for its adsorption. Batch adsorption studies were carried out in aqueous solution as a function of solution $\mathrm{pH}$, initial dye concentration, ionic strength and temperature. Various models were used to examine the adsorption kinetics, mechanism and equilibrium adsorption behavior of RBV onto chitosan 10B in aqueous solution. The reuse of chitosan 10B was investigated. The thermodynamics of the adsorption process was also studied.

\section{EXPERIMENTAL}

\section{Chemicals and preliminary characterization of chitosan}

Chitosan 10B (100\% deacetylated chitin, Katokichi Bio Co. Ltd., Japan) was used without further purification. The mass median diameters of the chitosan 10B flakes were estimated to be of $228 \pm 5$ $\mu \mathrm{m}$, using a laser scattering particle size analyzer (LDSA-240DA, Tonichi Computer Applications, Japan), equipped with a dry dispersing apparatus (PDIOS, Tonichi Computer Applications, Japan).

The dye Remazol Brilliant Violet (RBV) was bought from Sigma-Aldrich, Germany, and was used without further purification. The chemical structure of RBV is shown in Figure 1a. The other reagents used in this study were of pure analytical grade. Deionized water was prepared by passing distilled water through a deionizing column (Barnstead, Syboron Corporation, Boston, USA).

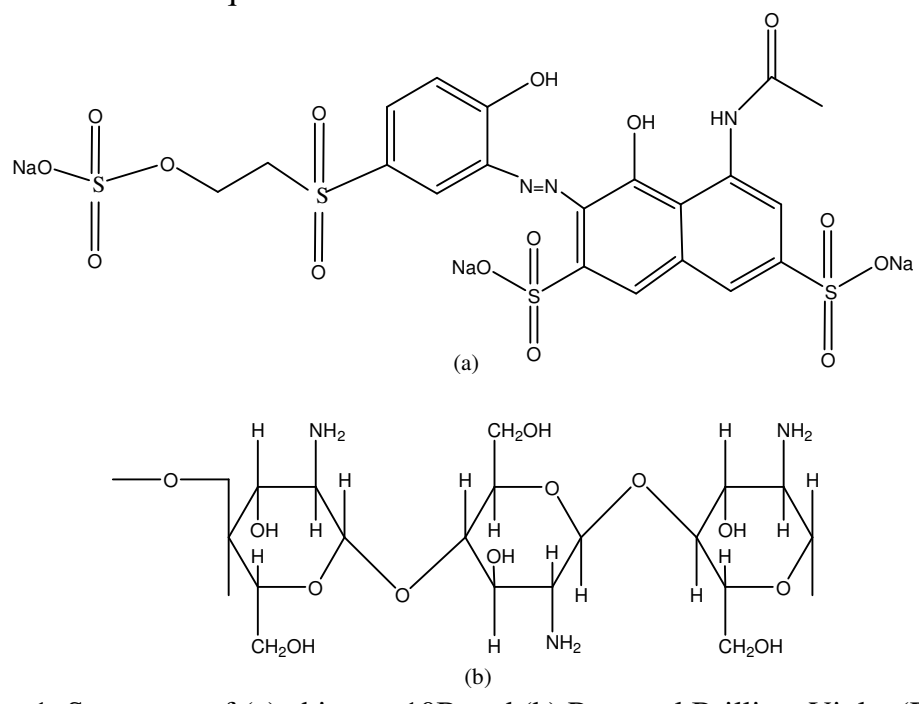

Figure 1: Structures of (a) chitosan 10B and (b) Remazol Brilliant Violet (RBV)

\section{Batch adsorption experiments}

In order to estimate the adsorption characteristics of RBV onto chitosan 10B flakes, batch adsorption studies were carried out in $125 \mathrm{~mL}$ stoppered bottles containing a fixed amount $(0.05 \mathrm{~g})$ of adsorbent and 25 $\mathrm{mL}$ of $100 \mu \mathrm{mol} / \mathrm{L}$ dye solution. ${ }^{20}$ The initial $\mathrm{pH}$ of the solution was adjusted with $1 \mathrm{~mol} / \mathrm{L} \mathrm{HCl}$ or $1 \mathrm{~mol} / \mathrm{L}$ $\mathrm{NaOH}$ solution, by using a $\mathrm{pH}$ meter (HANNA Instruments Microprocessor $\mathrm{pH}$ meter). The stoppered bottles were agitated in a thermostated shaker at room temperature $\left(31 \pm 0.2^{\circ} \mathrm{C}\right)$, with a speed of $120 \mathrm{r} / \mathrm{min}$, until reaching equilibrium. Each bottle was capped to avoid evaporation at high temperature. Samples were withdrawn at desired time intervals for analyzing the concentration of RBV in the solution. The samples were centrifuged at a speed of $4000 \mathrm{r} / \mathrm{min}$ for $5 \mathrm{~min}$. The concentration of RBV in the supernatant was determined by the spectrophotometric method, using a Shimadzu UV-1601PC spectrophotometer (Shimadzu, Japan), at $\lambda_{\max }$ value of $559 \mathrm{~nm}$. The $\lambda_{\max }(559 \mathrm{~nm})$ of the RBV solution was found to be constant in the $\mathrm{pH}$ range between 4 and 12 . The apparent molar absorptivity of RBV was estimated to be $8.6 \times 10^{3}$ $\mathrm{L} / \mathrm{mol} / \mathrm{cm}$ at $559 \mathrm{~nm}$ and $\mathrm{pH} 4-12$. The amount of RBV adsorbed at time $\mathrm{t}, q_{\mathrm{t}}(\mu \mathrm{mol} / \mathrm{g})$ was determined by: 


$$
q_{t}=\frac{V\left(C_{\mathrm{a}}-C_{t}\right)}{m}
$$

where $C_{0}(\mu \mathrm{mol} / \mathrm{L})$ and $C_{\mathrm{t}}(\mu \mathrm{mol} / \mathrm{L})$ are the liquidphase concentrations of RBV at initial and at any time $\mathrm{t}$, respectively, $V(\mathrm{~L})$ is the volume of the $\mathrm{RBV}$ solution and $m(\mathrm{~g})$ is the amount of dry chitosan 10B flakes used.

The adsorption kinetics was also investigated varying the initial concentration of the dye solutions (75-200 $\mu \mathrm{mol} / \mathrm{L})$, ionic strength (0.01-0.04 mol/L) and temperature $\left(36,41\right.$ and $\left.46{ }^{\circ} \mathrm{C}\right)$, respectively. The ionic strength of the dye solutions was adjusted with $1 \mathrm{~mol} / \mathrm{L}$ $\mathrm{Na}_{2} \mathrm{SO}_{4}$ solution. Equilibrium adsorption was performed at different temperatures of $31,36,41$ and $46{ }^{\circ} \mathrm{C}$, and at $\mathrm{pH} 4$ in the absence of $\mathrm{Na}_{2} \mathrm{SO}_{4}$.

The amount of RBV dye adsorbed onto chitosan $10 \mathrm{~B}$ at equilibrium time, $q_{\mathrm{e}}(\mu \mathrm{mol} / \mathrm{g})$, was determined by:

$$
q_{e}=\frac{v\left(C_{0}-C_{e}\right)}{m}
$$

where $C_{\mathrm{e}}(\mu \mathrm{mol} / \mathrm{L})$ is the liquid-phase concentration of $\mathrm{RBV}$ at equilibrium time; $C_{0}, V$ and $m$ remain the same as described above.

In the desorption study, $25 \mathrm{~mL}$ of $0.1 \mathrm{~mol} / \mathrm{L} \mathrm{NaOH}$ solution was used to desorb RBV from the chitosan 10B flakes. The adsorbent was contacted with $25 \mathrm{~mL}$ of $100 \mu \mathrm{mol} / \mathrm{L} \mathrm{RBV}$ solution for $120 \mathrm{~min}$, filtered and then dried at room temperature $\left(31^{\circ} \mathrm{C}\right)$ overnight. The dye loaded-adsorbent was transferred into $25 \mathrm{~mL}$ desorbing solution and the mixture was stirred for 120 min. The amount of adsorption was determined in the same way as described above. All the data presented in this paper are the mean of double measurements.

\section{RESULTS AND DISCUSSION Adsorption kinetics Effect of $p H$ on adsorption kinetics}

In this work, the effect of $\mathrm{pH}$ on the adsorption kinetics of RBV onto chitosan 10B flakes was studied in aqueous solution while the initial dye concentration, shaking time, amount of chitosan $10 \mathrm{~B}$ and temperature were fixed at $100 \mu \mathrm{mol} / \mathrm{L}$, $120 \mathrm{~min}, 0.05 \mathrm{~g}$ and $31{ }^{\circ} \mathrm{C}$, respectively. The results of $\mathrm{pH}$ effects on the adsorption kinetics of RBV by the chitosan 10B are presented in Figure 2 . The initial dye adsorption rate, $h$ ( $\mu \mathrm{mol} / \mathrm{g} \mathrm{min})$, and the amount of equilibrium dye adsorption, $q_{\mathrm{e}}$ $(\mu \mathrm{mol} / \mathrm{g})$, decreased significantly with increasing solution $\mathrm{pH}$ (Table 1). We noticed that the dye uptake reached equilibrium within $10 \mathrm{~min}$ at $\mathrm{pH}$ 4-5, 30 min at $\mathrm{pH}$ 6-9 and $45 \mathrm{~min}$ at $\mathrm{pH} \mathrm{10-12,}$ respectively (Fig. 2). However, the data were taken for $120 \mathrm{~min}$ to ensure that complete equilibrium was established. The amount of equilibrium dye adsorption $\left(q_{\mathrm{e}}\right)$ was found to be $58.25 \mu \mathrm{mol} / \mathrm{g}$ at $\mathrm{pH} 4$ and $31.78 \mu \mathrm{mol} / \mathrm{g}$ at $\mathrm{pH} 12$, respectively. These results can be explained on the basis of the charge developed over the surface of the adsorbent and dye ions as a result of the variation in the solution $\mathrm{pH}$. It has been reported that the $\mathrm{pH}_{\mathrm{zpc}}$ of chitosan is 6.3, and it undergoes $99 \%$ protonation at $\mathrm{pH} 4.3 .^{20}$ It is expected that positively charged functional groups on the adsorbent surface will favor the adsorption of negatively charged dye anions due to electrostatic attraction. At acidic $\mathrm{pH}$ values, the electrostatic attractions enhanced between the dye anions and the adsorption sites of chitosan, and dye adsorption increased. However, the positively charged sites of chitosan diminish with the increment of $\mathrm{pH}$, and the surface of chitosan becomes negatively charged. This situation does not benefit the adsorption of anionic dye and causes electrostatic repulsion. Hydroxyl ions are in competition with dye ions at high $\mathrm{pH}$, and the adsorption of the dye from aqueous solution decreases. Similar results were observed in the adsorption of anionic dyes in aqueous solution onto several other adsorbents. ${ }^{17,20,22}$ Hence, the $\mathrm{pH}$ of the aqueous solution plays a significant role on the adsorption rate and the amount of equilibrium RBV dye adsorption onto chitosan 10B (Table 1). The appropriate $\mathrm{pH}$ was found to be 4 , in the observed $\mathrm{pH}$ range from 4 to 12 , and hence, $\mathrm{pH} 4$ was selected for performing subsequent experiments.

\section{Effect of initial dye concentration on adsorption kinetics}

The effects of initial dye concentration on the adsorption kinetics of RBV onto chitosan 10B in aqueous solution $(\mathrm{pH} 4)$ at room temperature (31 ${ }^{\circ} \mathrm{C}$ ) are shown in Figure 3. It is observed that the dye adsorption was fast for the first $7 \mathrm{~min}$ and thereafter it proceeded at a slower rate and finally reached equilibrium. The dye uptake reached equilibrium within $15 \mathrm{~min}$ for $75 \mu \mathrm{mol} / \mathrm{L}$ and 75 $\min$ for $200 \mu \mathrm{mol} / \mathrm{L}$ RBV solutions, respectively. However, the data were taken for $120 \mathrm{~min}$ to ensure that complete equilibrium was established. As the initial concentration of the dye solution was increased from 75 to $200 \mu \mathrm{mol} / \mathrm{L}$, the equilibrium dye adsorption $\left(q_{\mathrm{e}}\right)$ increased from 38.81 to $99.46 \mu \mathrm{mol} / \mathrm{g}$ (Table 1 ). 
SUBARNA KARMAKER et al.

Table 1

Comparison of experimental and calculated $q_{\mathrm{e}}$ values, and kinetic parameters obtained from various kinetic models applied for the adsorption of RBV dye onto chitosan $10 \mathrm{~B}$ at different solution $\mathrm{pHs}$, initial concentrations of RBV, ionic strengths and temperatures

\begin{tabular}{|c|c|c|c|c|c|c|c|c|c|c|c|}
\hline \multirow{2}{*}{ 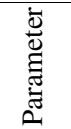 } & \multicolumn{4}{|c|}{ First-order kinetic model } & \multicolumn{4}{|c|}{ Second-order kinetic model } & \multicolumn{3}{|c|}{ Elovich model } \\
\hline & $\begin{array}{c}\mathrm{q}_{\mathrm{e}(\exp )} \\
(\mu \mathrm{mol} / \mathrm{g})\end{array}$ & $\begin{array}{c}\mathrm{k}_{1} \\
(1 / \mathrm{min})\end{array}$ & $\begin{array}{c}\mathrm{q}_{\mathrm{e}(\mathrm{cal})} \\
(\mu \mathrm{mol} / \mathrm{g})\end{array}$ & $R^{2}$ & $\begin{array}{c}\mathrm{k}_{2} \\
(\mathrm{~g} / \mu \mathrm{mol} \min )\end{array}$ & $\begin{array}{c}\mathrm{q}_{\mathrm{e}(\mathrm{cal})} \\
(\mu \mathrm{mol} / \mathrm{g})\end{array}$ & $\begin{array}{c}\mathrm{h} \\
(\mu \mathrm{mol} / \mathrm{g} \min )\end{array}$ & $R^{2}$ & $\begin{array}{c}\alpha \\
(\mu \mathrm{mol} / \mathrm{g} \min )\end{array}$ & $\begin{array}{c}\beta \\
(\mathrm{g} / \mu \mathrm{mol})\end{array}$ & $R^{2}$ \\
\hline \multicolumn{12}{|c|}{$\mathrm{pH}$} \\
\hline 4 & 58.25 & 0.1981 & 2.99 & 0.951 & 0.2113 & 58.14 & 714.29 & 1.000 & $1.46 \times 10^{45}$ & 1.8636 & 0.699 \\
\hline 5 & 55.83 & 0.1193 & 4.72 & 0.901 & 0.0801 & 55.87 & 250.00 & 1.000 & $1.94 \times 10^{23}$ & 1.0324 & 0.887 \\
\hline 6 & 54.17 & 0.1907 & 12.89 & 0.992 & 0.0498 & 54.35 & 147.16 & 1.000 & $4.57 \times 10^{10}$ & 0.5134 & 0.814 \\
\hline 7 & 51.82 & 0.2515 & 28.11 & 0.989 & 0.0326 & 52.08 & 88.49 & 0.999 & $3.09 \times 10^{6}$ & 0.3429 & 0.791 \\
\hline 8 & 50.51 & 0.1499 & 22.12 & 0.993 & 0.0179 & 51.02 & 46.73 & 0.999 & $2.34 \times 10^{4}$ & 0.2507 & 0.859 \\
\hline 9 & 48.87 & 0.1122 & 27.79 & 0.999 & 0.0086 & 50.25 & 21.83 & 0.999 & $3.58 \times 10^{2}$ & 0.1660 & 0.911 \\
\hline 10 & 44.89 & 0.1145 & 31.55 & 0.998 & 0.0070 & 46.73 & 15.31 & 0.999 & $0.96 \times 10^{2}$ & 0.1488 & 0.910 \\
\hline 11 & 38.85 & 0.1199 & 32.70 & 0.998 & 0.0064 & 40.82 & 10.76 & 0.999 & $0.39 \times 10^{2}$ & 0.1479 & 0.901 \\
\hline 12 & 31.78 & 0.1163 & 28.29 & 0.996 & 0.0067 & 33.67 & 7.55 & 0.999 & $0.22 \times 10^{2}$ & 0.1692 & 0.908 \\
\hline \multicolumn{12}{|c|}{$\mathrm{RBV}(\mu \mathrm{mol} / \mathrm{L})$} \\
\hline 75 & 38.81 & 0.1453 & 5.74 & 0.879 & 0.0641 & 38.91 & 97.09 & 1.000 & $9.95 \times 10^{10}$ & 0.7472 & 0.689 \\
\hline 100 & 52.32 & 0.1532 & 10.48 & 0.817 & 0.0380 & 52.63 & 105.26 & 1.000 & $2.69 \times 10^{7}$ & 0.3822 & 0.593 \\
\hline 125 & 63.81 & 0.1336 & 13.13 & 0.872 & 0.0256 & 64.52 & 106.38 & 1.000 & $2.54 \times 10^{7}$ & 0.3094 & 0.673 \\
\hline 150 & 75.18 & 0.1686 & 41.54 & 0.998 & 0.0103 & 76.34 & 60.24 & 0.999 & $8.18 \times 10^{3}$ & 0.1461 & 0.819 \\
\hline 200 & 99.46 & 0.0797 & 54.11 & 0.998 & 0.0031 & 102.04 & 32.79 & 0.999 & $3.87 \times 10^{2}$ & 0.0767 & 0949 \\
\hline \multicolumn{12}{|c|}{ Ionic strength $(\mathrm{mol} / \mathrm{L})$} \\
\hline 0.01 & 52.06 & 0.1096 & 5.52 & 0.955 & 0.0647 & 52.08 & 175.44 & 1.000 & $3.12 \times 10^{15}$ & 0.7587 & 0.763 \\
\hline 0.02 & 51.81 & 0.1108 & 6.68 & 0.952 & 0.0527 & 52.08 & 142.86 & 1.000 & $4.62 \times 10^{12}$ & 0.6324 & 0.776 \\
\hline 0.03 & 51.56 & 0.1177 & 7.69 & 0.944 & 0.0484 & 51.81 & 129.87 & 1.000 & $9.60 \times 10^{10}$ & 0.5576 & 0.759 \\
\hline 0.04 & 51.31 & 0.1122 & 7.99 & 0.943 & 0.0438 & 51.54 & 116.28 & 1.000 & $1.69 \times 10^{10}$ & 0.5256 & 0.768 \\
\hline \multicolumn{12}{|c|}{ Temperature $\left({ }^{\circ} \mathrm{C}\right)$} \\
\hline 31 & 51.81 & 0.1343 & 9.76 & 0.909 & 0.0534 & 52.08 & 144.93 & 1.000 & $7.44 \times 10^{8}$ & 0.4550 & 0.526 \\
\hline 36 & 52.06 & 0.1403 & 8.53 & 0.916 & 0.0640 & 52.36 & 175.44 & 1.000 & $3.83 \times 10^{10}$ & 0.5312 & 0.499 \\
\hline 41 & 52.50 & 0.1294 & 7.16 & 0.873 & 0.0737 & 52.63 & 204.08 & 1.000 & $8.86 \times 10^{11}$ & 0.5892 & 0.529 \\
\hline 46 & 52.88 & 0.0891 & 3.02 & 0.637 & 0.1323 & 52.91 & 370.37 & 1.000 & $1.06 \times 10^{19}$ & 0.9013 & 0.418 \\
\hline
\end{tabular}




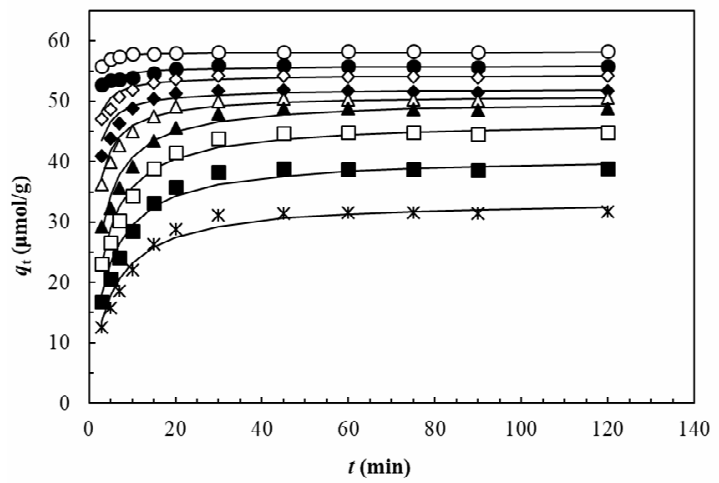

Figure 2: Adsorption kinetics of RBV onto chitosan 10B at various $\mathrm{pH}\left([\mathrm{RBV}]_{0}: 100 \mu \mathrm{mol} / \mathrm{L}\right.$; solution volume: $25 \mathrm{~mL}$; chitosan 10B: $0.05 \mathrm{~g}$; temperature: $31{ }^{\circ} \mathrm{C}$; solution pHs: ०: $\mathrm{pH} 4 ; \bullet: \mathrm{pH} 5 ; \diamond: \mathrm{pH} 6 ; \diamond: \mathrm{pH} 7 ; \Delta: \mathrm{pH}$ 8; $\mathbf{\Delta}: \mathrm{pH}$ 9; $\square: \mathrm{pH} \mathrm{10;} \mathbf{p} \mathrm{pH} \mathrm{11;*:} \mathrm{pH} 12$ ); (solid lines are generated numerically based on pseudo-secondorder adsorption kinetic profiles using Eq. (4) and the values of $\mathrm{q}_{\mathrm{e}(\mathrm{cal})}$ and $\mathrm{k}_{2}$ from Table 1)

The initial concentration of the dye solution affords a notable dynamic force to overwhelm the mass transfer resistance of all the molecules between the aqueous and solid phases. ${ }^{20}$ Similar phenomena were also observed in the adsorption of Congo Red onto perlite ${ }^{7}$ and Reactive Black 5 (RB5) onto chitosan ${ }^{22}$ in aqueous solution, respectively.

\section{Effect of ionic strength on adsorption kinetics}

The presence of different salts in textile wastewater should be taken into consideration, since different salts (sodium sulphate, sodium chloride) are used in industrial dyeing in order to obtain uniform coloration. Therefore, various salts and metal ions could exist in wastewater and their concentration (ionic strength) affects significantly the performance of the adsorption process. In this study, sodium sulphate was used in varying salt concentration from 0.01 to $0.04 \mathrm{~mol} / \mathrm{L}$ for dye solutions with an initial concentration of 100 $\mu \mathrm{mol} / \mathrm{L}$. Figure 4 shows important reductions in initial dye adsorption rate, $h(\mu \mathrm{mol} / \mathrm{g} \min )$, and the amount of equilibrium dye adsorption, $q_{\mathrm{e}}$ $(\mu \mathrm{mol} / \mathrm{g})$, with the increase in solution ionic strength (Table 1). The adsorption process is governed by electrostatic interactions between the cationic charged surface of chitosan 10B particles and anionic dye molecules. The decrease in the initial rate of dye adsorption and the amount of equilibrium dye adsorption could be due to an

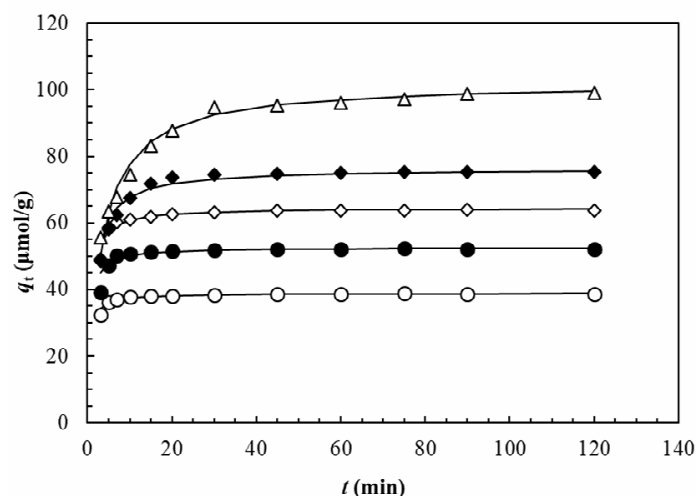

Figure 3: Adsorption kinetics of RBV onto chitosan 10B in aqueous solution $(\mathrm{pH} 4)$ at various initial dye concentrations (solution volume: $25 \mathrm{~mL}$; chitosan 10B: $0.05 \mathrm{~g}$; temperature: $31{ }^{\circ} \mathrm{C}$; $[\mathrm{RBV}]_{0}$ : ०: $75 \mu \mathrm{mol} / \mathrm{L}$; •: $100 \mu \mathrm{mol} / \mathrm{L} ; \diamond: 125 \mu \mathrm{mol} / \mathrm{L} ; \bullet: 150 \mu \mathrm{mol} / \mathrm{L} ; \Delta: 200$ $\mu \mathrm{mol} / \mathrm{L}$ ); (solid lines are generated numerically based on pseudo-second-order adsorption kinetic profiles using Eq. (4) and the values of $\mathrm{q}_{\mathrm{e}(\mathrm{cal})}$ and $\mathrm{k}_{2}$ from Table 1)

electrostatic screening effect, which is well known as electrostatic interaction between polycationic chitosan and $\mathrm{SO}_{3}^{-}$anions. The structure of the diffuse layer is determined by electrostatic interactions described by the GouyChapman theory and it is well known that the high ionic strength produces compression of the diffuse layer. These results are in agreement with those of other adsorption studies., ${ }^{2,15,20}$

\section{Effect of temperature on adsorption kinetics}

The effect of temperature on the adsorption kinetics of RBV onto chitosan 10B in aqueous solution ( $\mathrm{pH} \mathrm{4}$ ) is shown in Figure 5, where the initial concentration of the dye solution was 100 $\mu \mathrm{mol} / \mathrm{L}$. Below and above the equilibrium time, an increase in solution temperature leads to an increase in both the initial rate, $h(\mu \mathrm{mol} / \mathrm{g} \mathrm{min})$, and the amount of equilibrium dye adsorption, $q_{\mathrm{e}}$ $(\mu \mathrm{mol} / \mathrm{g}),($ Table 1$)$, which indicates a kinetically controlled endothermic adsorption process. ${ }^{20}$ Therefore, higher temperatures facilitate the adsorption of RBV onto chitosan 10B flakes, because the mobility of dye molecules increased with rising solution temperature, and it suggests that the dye molecules interacted more effectively with the functional groups on chitosan flakes at high temperature. ${ }^{19}$ Similar results were also observed in the adsorption of Reactive Yellow 145 and Reactive Black 5 onto chitosan in aqueous solutions, respectively. ${ }^{20,22}$ 


\section{Kinetic analysis}

The rate and the mechanism of the adsorption process can be elucidated on the basis of a kinetic study. The kinetics of RBV dye adsorption onto chitosan 10B in aqueous solution under various conditions may be explained by pseudo-firstorder, ${ }^{28}$ pseudo-second-order, ${ }^{29}$ Elovich $^{30}$ and intraparticle diffusion ${ }^{31}$ kinetic models, respectively. The pseudo-first-order rate expression is given as:

$$
\log \left(q_{\mathrm{e}}-q_{\mathrm{t}}\right)=\log q_{\mathrm{e}}-\frac{k_{1}}{2.303} t
$$

where $q_{\mathrm{t}}(\mu \mathrm{mol} / \mathrm{g})$ and $q_{\mathrm{e}}(\mu \mathrm{mol} / \mathrm{g})$ are the amounts of dye adsorbed on chitosan 10B at time $t$ and at equilibrium, respectively, and $k_{1}(1 / \mathrm{min})$ is the rate constant of pseudo-first-order adsorption. A straight line of $\log \left(q_{\mathrm{e}}-q_{\mathrm{t}}\right)$ versus $t$ suggests the applicability of the pseudo-first-order kinetic model to fit the experimental data.

The pseudo-second-order kinetic model is

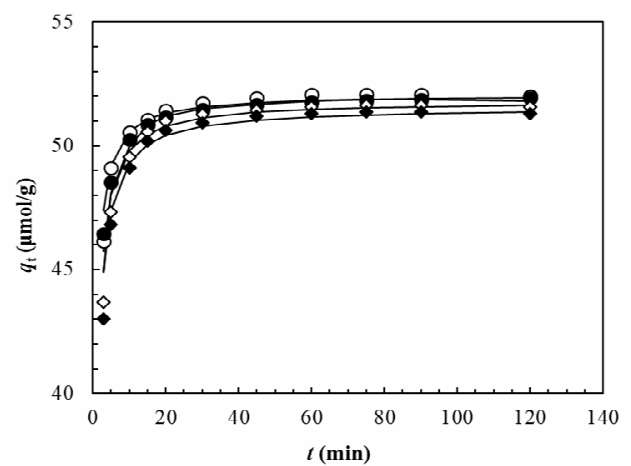

Figure 4: Effects of ionic strength on adsorption kinetics of RBV onto chitosan $10 \mathrm{~B}$ in aqueous solution ([RBV $]_{0}$ : $100 \mu \mathrm{mol} / \mathrm{L}$; solution volume: $25 \mathrm{~mL}$; chitosan 10B: $0.05 \mathrm{~g}$; temperature: $31{ }^{\circ} \mathrm{C}$; ionic strength: $\circ$ : 0.01 $\mathrm{mol} / \mathrm{L} ; \bullet: 0.02 \mathrm{~mol} / \mathrm{L} ; \diamond: 0.03 \mathrm{~mol} / \mathrm{L} ; \diamond: 0.04 \mathrm{~mol} / \mathrm{L}$ ); (solid lines are generated numerically based on pseudosecond-order adsorption kinetic profiles using Eq. (4) and the values of $\mathrm{q}_{\mathrm{e}(\mathrm{cal})}$ and $\mathrm{k}_{2}$ from Table 1)

The Elovich model has been also used to interpret the kinetics of adsorption. This model is useful in describing predominantly chemical adsorption onto highly heterogeneous adsorbents. The linear form of the Elovich equation is given by:

$$
q_{\mathrm{t}}=\frac{1}{\beta} \ln (\alpha \beta)-\frac{1}{\beta} \ln t
$$

where $\alpha(\mu \mathrm{mol} / \mathrm{g} \min )$ represents the initial adsorption rate and $\beta(\mathrm{g} / \mu \mathrm{mol})$ is related to the extent of surface coverage and the activation expressed as:

$q_{t}=\frac{k_{2} q_{e}^{2} t}{\left(1+k_{2} q_{e} t\right)}$

where $k_{2}(\mathrm{~g} / \mu \mathrm{mol} \mathrm{min})$ is the rate constant of pseudo-second-order adsorption and can be determined from the linearized form of this equation, represented by Equation (5):

$\frac{t}{q_{\mathrm{t}}}=\frac{1}{k_{2} q_{\mathrm{e}}^{2}}+\frac{1}{q_{\mathrm{e}}} t$

If second-order kinetics is pertinent, the plot of $t / q_{\mathrm{t}}$ versus $t$ should reveal a linear relationship. There is no need to know any parameter beforehand and the amount of equilibrium adsorption $\left(q_{\mathrm{e}}\right)$ can be calculated from Equation (5) and also, the initial adsorption rate, $h(\mu \mathrm{mol} / \mathrm{g}$ $\min$ ), can be obtained by:

$$
h=k_{2} q_{\mathrm{e}}^{2}
$$

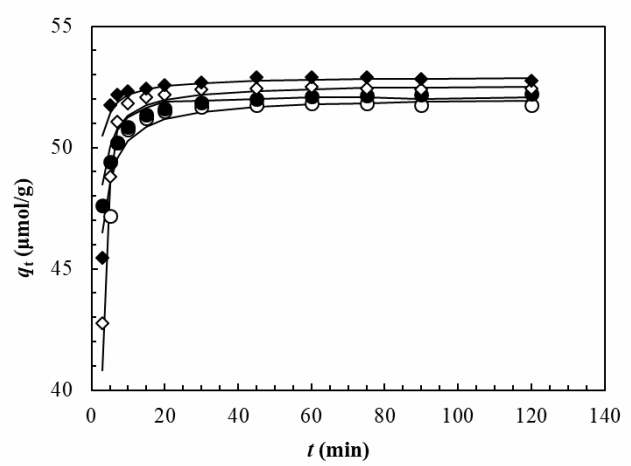

Figure 5: Adsorption kinetics of RBV onto chitosan 10B in aqueous solution at various temperatures $\left([\mathrm{RBV}]_{0}\right.$ : $100 \mu \mathrm{mol} / \mathrm{L}$; solution volume: $25 \mathrm{~mL}$; chitosan 10B: $0.05 \mathrm{~g}$; temperature: $\circ: 31{ }^{\circ} \mathrm{C} ; \bullet: 36{ }^{\circ} \mathrm{C} ; \diamond: 41{ }^{\circ} \mathrm{C} ; \bullet: 46$ ${ }^{\circ} \mathrm{C}$ ); (solid lines are simulated pseudo-second-order adsorption kinetic profiles generated numerically using Eq. (4) and the values of $\mathrm{q}_{\mathrm{e}(\mathrm{cal})}$ and $\mathrm{k}_{2}$ from Table 1)

energy for chemisorption. Elovich parameters $\alpha$ and $\beta$ might be calculated from the plot of $q_{\mathrm{t}}$ versus $\ln t$.

The values of correlation coefficients $\left(R^{2}\right)$ and various kinetic parameters obtained from the applied kinetic models are shown in Table 1. The values of $R^{2}$ were $\leq 0.998$ for the pseudo-firstorder kinetics model and $\leq 0.949$ for the Elovich model in all the cases. Also, the computed $q_{\text {e(cal) }}$ values achieved from the pseudo-first-order kinetic model do not give reasonable values, 
which were too small compared with the experimental $q_{\text {e(exp) }}$ values (Table 1). These results suggest that the adsorption kinetics of RBV onto chitosan 10B in aqueous solution do not fit with the pseudo-first-order and Elovich models.

On the other hand, the slopes and y-intercepts of the plots of $t / q_{\mathrm{t}}$ versus $t$ were used to calculate the pseudo-second-order rate constant $\left(k_{2}\right)$ and $q_{\mathrm{e}}$, respectively. The plots of $t / q_{\mathrm{t}}$ versus $t$ showed straight lines, with good agreement with the experimental data taken for various solution $\mathrm{pHs}$, initial dye concentrations, ionic strengths and temperatures. The values of $R^{2}$ for the pseudosecond-order kinetic model are $\geq 0.999$ in almost

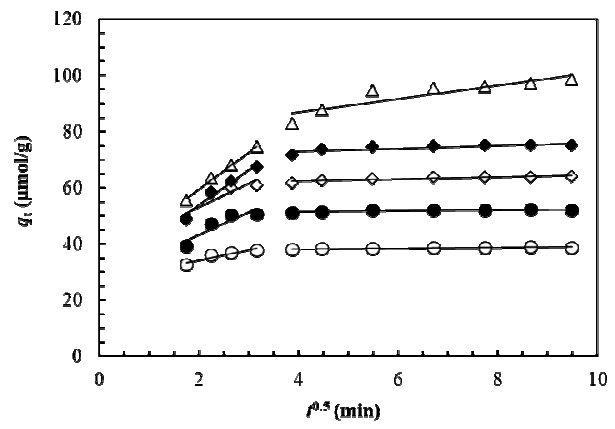

Figure 6: Intraparticle diffusion model plots for the adsorption of RBV dye on chitosan $10 \mathrm{~B}$ at various initial concentrations (solution volume: $25 \mathrm{~mL}$; chitosan 10B: $0.05 \mathrm{~g}$; temperature: $31{ }^{\circ} \mathrm{C}$; $[\mathrm{RBV}]_{0}$ : ०: $75 \mu \mathrm{mol} / \mathrm{L} ; \bullet: 100 \mu \mathrm{mol} / \mathrm{L} ; \diamond: 125 \mu \mathrm{mol} / \mathrm{L} ; \bullet: 150$ $\mu \mathrm{mol} / \mathrm{L} ; \Delta: 200 \mu \mathrm{mol} / \mathrm{L}$ ); (the constant values are listed in Table 2) all the cases. The values of the calculated amount of equilibrium dye adsorption $\left(q_{\text {e(cal })}\right)$ also agree very well with the experimental values of $q_{\mathrm{e}(\exp )}$ (Table 1), indicating a favorable condition for pseudo-second-order adsorption kinetics.

The diffusion mechanism can be identified by using the intraparticle diffusion model proposed by Weber et al. in $1963 .^{31}$

$$
q_{\mathrm{t}}=k_{\mathrm{id}} \mathrm{t}^{0.5}+I
$$

where $k_{\mathrm{id}}\left(\mu \mathrm{mol} / \mathrm{g} \min ^{0.5}\right)$ is the intraparticle diffusion rate constant and $I(\mu \mathrm{mol} / \mathrm{g})$ is the intercept.

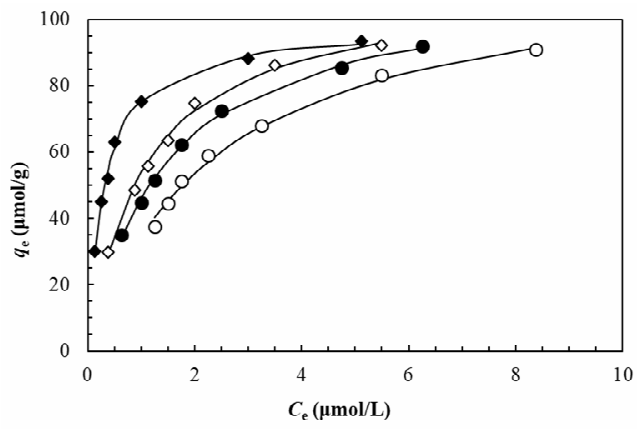

Figure 7: Typical equilibrium adsorption isotherm of RBV on chitosan 10B in aqueous solution at different temperatures $\left([\mathrm{RBV}]_{0}: 75-200 \mu \mathrm{mol} / \mathrm{L}\right.$; solution volume: $25 \mathrm{~mL}$; chitosan: $0.05 \mathrm{~g}$; solution $\mathrm{pH} 4$; temperatures: $\circ$ : $31^{\circ} \mathrm{C} ; \bullet: 36^{\circ} \mathrm{C} ; \diamond: 41^{\circ} \mathrm{C} ; \bullet: 46^{\circ} \mathrm{C}$ ); (solid lines are simulated Langmuir equilibrium adsorption isotherms at respective temperatures, generated using the Langmuir model in Eq. (19) and the Langmuir isotherm constants from Table 3)

Table 2

Diffusion rate parameters $\left(k_{\mathrm{id} 1}\right.$ and $\left.k_{\mathrm{id} 2}\right)$ for the adsorption of RBV onto chitosan 10B in aqueous solution under various conditions

\begin{tabular}{|c|c|c|c|c|c|c|}
\hline Parameters & $\begin{array}{c}\mathrm{k}_{\mathrm{id} 1} \\
\left(\mu \mathrm{mol} / \mathrm{g} \min ^{0.5}\right)\end{array}$ & $\begin{array}{c}\mathrm{I}_{1} \\
(\mu \mathrm{mol} / \mathrm{g})\end{array}$ & $R^{2}$ & $\begin{array}{c}\mathrm{k}_{\mathrm{id} 2} \\
\left(\mu \mathrm{mol} / \mathrm{g} \min ^{0.5}\right)\end{array}$ & $\begin{array}{c}\mathrm{I}_{1} \\
(\mu \mathrm{mol} / \mathrm{g})\end{array}$ & $R^{2}$ \\
\hline \multicolumn{7}{|c|}{$\mathrm{pH}$} \\
\hline 4 & 1.697 & 54.096 & 0.959 & 0.186 & 57.475 & 0.949 \\
\hline 5 & 0.882 & 51.335 & 0.973 & 0.068 & 56.405 & 0.924 \\
\hline 6 & 3.450 & 41.146 & 0.981 & 0.121 & 53.073 & 0.341 \\
\hline 7 & 5.509 & 31.550 & 0.997 & 0.122 & 50.693 & 0.293 \\
\hline 8 & 6.211 & 25.758 & 0.989 & 0.371 & 47.217 & 0.534 \\
\hline 9 & 6.689 & 17.727 & 0.997 & 0.493 & 44.538 & 0.559 \\
\hline 10 & 7.519 & 10.111 & 0.997 & 0.538 & 40.260 & 0.612 \\
\hline 11 & 7.717 & 3.570 & 0.997 & 0.458 & 34.927 & 0.524 \\
\hline 12 & 6.477 & 1.432 & 0.999 & 0.427 & 28.005 & 0.578 \\
\hline \multicolumn{7}{|c|}{$[\mathrm{RBV}](\mu \mathrm{mol} / \mathrm{L})$} \\
\hline 75 & 3.535 & 27.157 & 0.869 & 0.124 & 37.630 & 0.857 \\
\hline 100 & 8.005 & 27.232 & 0.828 & 0.169 & 50.767 & 0.790 \\
\hline 125 & 8.405 & 36.348 & 0.794 & 0.324 & 61.113 & 0.788 \\
\hline 150 & 12.422 & 29.015 & 0.965 & 0.498 & 71.020 & 0.699 \\
\hline 200 & 13.042 & 33.450 & 0.994 & 2.399 & 77.333 & 0.807 \\
\hline
\end{tabular}




\begin{tabular}{ccccccc}
\hline \multicolumn{7}{c}{ Ionic strength $(\mathrm{mol} / \mathrm{L})$} \\
\hline 0.01 & 1.740 & 44.277 & 0.825 & 0.044 & 51.619 & 0.497 \\
0.02 & 2.123 & 42.428 & 0.869 & 0.059 & 51.279 & 0.640 \\
0.03 & 2.489 & 40.721 & 0.874 & 0.059 & 51.029 & 0.640 \\
0.04 & 2.593 & 39.925 & 0.872 & 0.068 & 50.697 & 0.629 \\
\hline \multicolumn{7}{c}{ Temperatures $\left({ }^{\circ} \mathrm{C}\right)$} \\
\hline 31 & 5.073 & 33.841 & 0.696 & 0.032 & 51.479 & 0.464 \\
41 & 4.462 & 36.408 & 0.671 & 0.025 & 51.809 & 0.674 \\
46 & 3.967 & 38.469 & 0.717 & 0.026 & 52.149 & 0.362 \\
\hline
\end{tabular}

The rate-controlling step is an intraparticle diffusion if the plot of the dye adsorbed $\left(q_{\mathrm{t}}\right)$ against the square root of contact time $\left(t^{0.5}\right)$ leads to a straight line passing through the origin. When the plots do not pass through the origin, it is an indication of some degree of boundary layer control and the intraparticle diffusion is not the only rate-limiting step. In this case, the adsorption process is complex and more kinetic models that operate simultaneously may control the rate of dye adsorption. ${ }^{20}$ The values of the intraparticle diffusion rate constant $\left(k_{\mathrm{id}}\right)$ were obtained from the linear part of the plots $q_{\mathrm{t}} v s . t^{0.5}$ for RBV adsorption onto chitosan 10B in aqueous solution at various dye concentrations (Fig. 6).

In the range of initial dye concentration of 75$200 \mu \mathrm{mol} / \mathrm{L}$, two separate regions are found in the plots (Fig. 6); namely, the first linear part can be attributed to the macropore diffusion (rate constant $\left.k_{\mathrm{id} 1}\right)$ and the second linear portion - to the micropore diffusion (rate constant $k_{\mathrm{id} 2}$ ). The values of $k_{\mathrm{id} 1}$ and $k_{\mathrm{id} 2}$ increase with increasing initial dye concentration (Table 2), which corresponds to an enhanced diffusion of the dye molecules from the outer surface of the adsorbent into macropores and micropores. Similar phenomena were also observed in the adsorption of Reactive Red 3 and Direct Brown 95 dyes onto chitosan. $^{21}$

On the other hand, both $k_{\text {id1 }}$ and $k_{\text {id2 }}$ values decreased with the increase in solution temperatures (from 31 to $46{ }^{\circ} \mathrm{C}$ ) (Table 2). In 2007, Cheung et al. $^{23}$ described analogous activities of chitosan towards acid dye and confirmed that during acid dye adsorption onto chitosan, the mechanism was predominantly intraparticle diffusion, but there was also a dependence on pore size, as the dye diffuses into macropores, mesopores and micropores, respectively.

The values of $k_{2}$ at different temperatures listed in Table 1 were used to estimate the activation energy for RBV adsorption onto chitosan 10B in aqueous solution. Assuming that the correlation among the rate constant $\left(k_{2}\right)$, temperature $(T)$ and activation energy $\left(E_{\mathrm{a}}\right)$ follows the Arrhenius equation, this would lead to the following expression:

$$
\ln k_{2}=-\frac{E_{a}}{R}\left(\frac{1}{T}\right)+\text { const } \text {. }
$$

where $R$ is the gas constant $(8.314 \mathrm{~J} / \mathrm{mol} \mathrm{K})$. The slope of plot of $\ln k_{2}$ versus $1 / T\left(R^{2}=0.996\right)$ was used to evaluate $E_{\mathrm{a}}$, which was estimated to be $25.52 \mathrm{~kJ} / \mathrm{mol}$ for the adsorption of RBV onto chitosan 10B in aqueous solution in the temperature range of $31-46{ }^{\circ} \mathrm{C}$, and initial dye concentration of $100 \mu \mathrm{mol} / \mathrm{L}$. The chemisorption and physisorption mechanisms are frequently a principal sign to express the type of interaction between the dye molecule and the adsorbent. The physisorption processes typically have energies in the range of $4-40 \mathrm{~kJ} / \mathrm{mol}$, while higher activation energies $(40-400 \mathrm{~kJ} / \mathrm{mol})$ suggest chemisorption. ${ }^{20}$ Here, the obtained value of the activation energy $\left(E_{\mathrm{a}}: 25.52 \mathrm{~kJ} / \mathrm{mol}\right)$ is low and thus, the sorption of RBV onto chitosan 10B in aqueous solution may be a physisorption process.

\section{Equilibrium adsorption}

Adsorption isotherms are preconditions to recognize the nature of the interaction between the adsorbate and the adsorbent used for the removal of organic pollutants. A plot of the amount of equilibrium dye adsorption, $q_{\mathrm{e}}$ $(\mu \mathrm{mol} / \mathrm{g})$, versus the liquid phase $\mathrm{RBV}$ equilibrium concentration, $C_{\mathrm{e}}(\mu \mathrm{mol} / \mathrm{L})$, in aqueous solution ( $\mathrm{pH} 4)$ at various temperatures is shown in Figure 7.

The amount of equilibrium dye adsorption onto chitosan 10B increased when the solution temperature was increased from 31 to $46{ }^{\circ} \mathrm{C}$. The experimental data have been analyzed by Freundlich, Temkin, Dubinin-Radushkevich and Langmuir isotherm models, respectively. ${ }^{32-35}$ The isotherm constants were obtained from the linearized plots of the respective isotherm 
equations and the values of the correlation coefficients $\left(R^{2}\right)$ are shown in Table 3.

\section{Freundlich isotherm}

The well-known Freundlich isotherm is based on sorption to a heterogeneous surface or surfaces supporting sites of varied affinities. It is assumed that the stronger binding sites are occupied first and that the binding strength decreases with an increasing degree of site occupation. The Freundlich equation is given as:

$$
q_{e}=K_{F} C_{e}^{\frac{1}{n}}
$$

Equation (10) can be linearized by taking the logarithms to find out the parameters $\mathrm{K}_{\mathrm{F}}$ and $1 / \mathrm{n}$.

$$
\ln q_{e}=\frac{1}{n} \ln C_{e}+\ln K_{F}
$$

where $K_{\mathrm{F}}$ is roughly an indicator of the adsorption capacity $\left((\mu \mathrm{mol} / \mathrm{g})(\mu \mathrm{mol} / \mathrm{L})^{-1 / n}\right)$ and $n$ is related to the intensity of adsorption. $K_{\mathrm{F}}$ and $n$ can be determined from the linear plot of $\ln q_{\mathrm{e}}$ versus $\ln C_{\mathrm{e}}$. The calculated results are listed in Table 3. The magnitude of the exponent $n$ gives an indication of the favorability of adsorption. From Table 3, the exponent $n$ is larger than 1 for the adsorption of RBV by chitosan 10B in aqueous solution at different temperatures, indicating favorable adsorption conditions. ${ }^{36}$

\section{Temkin isotherm}

Temkin isotherm contains a factor that explicitly takes into account the adsorbing species-adsorbate interactions. This isotherm assumes that: (i) the heat of adsorption of all the molecules in the layer decreases linearly with coverage due to adsorbent-adsorbate interactions, and (ii) adsorption is characterized by a uniform distribution of binding energies. The Temkin isotherm is represented by the following equation:

$$
q_{e}=\left(\frac{R T}{b}\right) \ln \left(K_{T} C_{e}\right)
$$

Equation (12) can be expressed in its linear form as:

$$
q_{\mathrm{e}}=B_{1} \ln K_{T}+B_{1} \ln C_{e}
$$

where:

$$
B_{1}=\frac{R T}{b}
$$

and $K_{\mathrm{T}}(\mu \mathrm{mol} / \mathrm{L})$ is the Temkin isotherm constant, $b(\mathrm{~J} / \mathrm{mol})$ is a constant related to the heat of sorption, $R$ is the gas constant $(8.314 \mathrm{~J} / \mathrm{mol} \mathrm{K})$ and $T$ is the absolute temperature $(K)$. A plot of $q_{\mathrm{e}}$ versus $\ln C_{\mathrm{e}}$ enables the determination of the isotherm constants $b$ and $K_{\mathrm{T}}$ from the slope and intercept, respectively. The calculated parameters and correlation coefficients are listed in Table 3. The heat of adsorption changed linearly with coverage due to adsorbent-adsorbate interaction. The correlation coefficients $\left(R^{2}\right)$ of the Temkin isotherm are $0.989,0.994,0.988$, and 0.972 at 31 , 36, 41 and $46{ }^{\circ} \mathrm{C}$, respectively. The poor correlation coefficient values showed that the experimental data were not in good agreement with the Temkin model.

\section{Dubinin-Radushkevich isotherm}

The Dubinin-Radushkevich isotherm equation used to estimate the characteristic porosity of the adsorbent and the apparent energy of adsorption, which is given by Equation (15):

$$
q_{e}=q_{D R} \exp \left(-K_{D R} \varepsilon^{2}\right)
$$

Equation (15) can be expressed in its linear form as:

$$
\ln q_{e}=\ln q_{D R}-K_{D R} \varepsilon^{2}
$$

Polanyi potential $(\varepsilon)$ is given as Equation (17):

$$
\varepsilon=\mathrm{RT} \ln \left(1-\frac{1}{c_{e}}\right)
$$

The plot of $\ln q_{\mathrm{e}}$ versus $\varepsilon^{2}$ gives a straight line with a slope of $-K_{D R}$ and an intercept of $\ln q_{\mathrm{DR}}$. The Dubinin-Radushkevich constant can give valuable information regarding the mean energy of adsorption by Equation (18):

$$
E=\frac{1}{\left(2 K_{D R}\right)^{0.5}}
$$

The calculated parameters and correlation coefficients are listed in Table 3. The correlation coefficients $\left(R^{2}\right)$ of the Dubinin-Radushkevich isotherm are $0.978,0.918,0.915$ and 0.968 at 31 , 36, 41 and $46{ }^{\circ} \mathrm{C}$, respectively. The poor correlation coefficient values showed that the experimental data were not in good agreement with the Dubinin-Radushkevich model.

Meanwhile, from the Dubinnin-Radushkevich isotherm, the mean adsorption energy $(E)$ involved the transfer of the free energy of one mole of solute from infinity (in solution) to the adsorbent surface. The adsorption behavior might have predicted the physical adsorption in the range of $1-8 \mathrm{~kJ} / \mathrm{mol}$ of the mean adsorption energy, and the chemical adsorption in more than $8 \mathrm{~kJ} / \mathrm{mol}$ of the mean adsorption energy. ${ }^{37,38}$ The mean adsorption energies $(E)$ for the adsorption of $\mathrm{RBV}$ onto chitosan $10 \mathrm{~B}$ in aqueous was found to 
be in the range from 1.118 to $4.082 \mathrm{~kJ} / \mathrm{mol}$, which indicates that the present dye adsorption predominates over the physical adsorption process.

\section{Langmuir isotherm}

The commonly used Langmuir isotherm has found successful application in many real sorption processes and is expressed as:

$$
q_{e}=\frac{k_{L} c_{e}}{\left(1+a_{L} C_{e}\right)}
$$

The constants $K_{\mathrm{L}}$ and $\mathrm{a}_{\mathrm{L}}$ are the characteristics of the Langmuir equation and can be determined from the linearized form of this equation, represented by Equation (20):

$$
\frac{c_{e}}{q_{e}}=\frac{1}{K_{L}}+\frac{a_{L}}{K_{L}} C_{e}
$$

Therefore, the plot of $C_{\mathrm{e}} / q_{\mathrm{e}}$ versus $C_{\mathrm{e}}$ gives a straight line with the slope $a_{\mathrm{L}} / K_{\mathrm{L}}$ and $y$-intercept $1 / K_{\mathrm{L}}$. The constant $\mathrm{a}_{\mathrm{L}}$ is the Langmuir equilibrium constant and the ratio $\mathrm{a}_{\mathrm{L}} / K_{\mathrm{L}}$ gives the inverse of theoretical monolayer saturation capacity $\left(q_{\mathrm{m}}\right)$. The values of $\mathrm{a}_{\mathrm{L}}$ and $K_{\mathrm{L}}$ were computed from the slopes and $y$-intercepts of different linearized plots of $\left(C_{\mathrm{e}} / q_{\mathrm{e}}\right)$ versus $C_{\mathrm{e}}$ represented at different temperatures. The calculated results are shown in Table 3.

The fits are quite good for all the four different temperatures under the concentration range studied (correlation coefficient, $R^{2} \geq 0.989$ ). Comparing the linear correlation coefficients listed in Tables 3, it could also be concluded that the equilibrium adsorption of RBV dye onto chitosan 10B in aqueous solution fitted very well with the Langmuir isotherm equation. The high degree of the linear correlation coefficient $\left(R^{2}\right)$ also suggests that a single surface reaction with constant activation energy is the predominant sorption step and possibly the predominant ratecontrolling step. ${ }^{39}$

Table 3

Freundlich, Temkin, Dubinin-Radushkevich and Langmuir isotherm constants at different temperatures and

\begin{tabular}{|c|c|c|c|c|}
\hline Parameters & \multicolumn{4}{|c|}{ Freundlich isotherm } \\
\hline $\mathrm{T}\left({ }^{\circ} \mathrm{C}\right)$ & 31 & 36 & 41 & 46 \\
\hline $\mathrm{K}_{\mathrm{F}}\left((\mu \mathrm{mol} / \mathrm{g})(\mu \mathrm{mol} / \mathrm{L})^{-1 / \mathrm{n}}\right)$ & 37.993 & 45.801 & 50.360 & 66.062 \\
\hline $\mathrm{N}$ & 2.241 & 2.409 & 2.347 & 3.497 \\
\hline$R^{2}$ & 0.951 & 0.969 & 0.953 & 0.906 \\
\hline Parameters & \multicolumn{4}{|c|}{ Temkin isotherm } \\
\hline $\mathrm{T}\left({ }^{\circ} \mathrm{C}\right)$ & 31 & 36 & 41 & 46 \\
\hline $\mathrm{K}_{\mathrm{T}}(\mu \mathrm{mol} / \mathrm{L})$ & 3.417 & 3.874 & 4.056 & 7.420 \\
\hline $\mathrm{b}(\mathrm{J} / \mathrm{mol})$ & 90.811 & 101.715 & 106.882 & 155.416 \\
\hline$R^{2}$ & 0.989 & 0.994 & 0.986 & 0.972 \\
\hline Parameters & \multicolumn{4}{|c|}{ Dubinin-Radushkevich isotherm } \\
\hline $\mathrm{T}\left({ }^{\circ} \mathrm{C}\right)$ & 31 & 36 & 41 & 46 \\
\hline $\mathrm{q}_{\mathrm{DR}}(\mu \mathrm{mol} / \mathrm{g})$ & 87.400 & 83.029 & 82.426 & 85.841 \\
\hline $\mathrm{K}\left(\mathrm{J}^{2} / \mathrm{mol}^{2}\right)$ & $4.000 \times 10^{-7}$ & $2.000 \times 10^{-7}$ & $9.000 \times 10^{-8}$ & $3.000 \times 10^{-8}$ \\
\hline $\mathrm{E}(\mathrm{kJ} / \mathrm{mol})$ & 1.1180 & 1.5811 & 2.3570 & 4.0824 \\
\hline$R^{2}$ & 0.978 & 0.918 & 0.915 & 0.968 \\
\hline Parameters & \multicolumn{4}{|c|}{ Langmuir isotherm } \\
\hline $\mathrm{T}\left({ }^{\circ} \mathrm{C}\right)$ & 31 & 36 & 41 & 46 \\
\hline $\mathrm{K}_{\mathrm{L}}(\mathrm{L} / \mathrm{g})$ & 49.019 & 78.125 & 104.167 & 322.581 \\
\hline $\mathrm{a}_{\mathrm{L}}(\mathrm{L} / \mu \mathrm{mol})$ & 0.4167 & 0.6953 & 0.9375 & 3.2903 \\
\hline $\mathrm{q}_{\mathrm{m}}(\mu \mathrm{mol} / \mathrm{g})$ & 117.65 & 112.36 & 111.11 & 98.04 \\
\hline$R_{\mathrm{L}}$ & 0.012 & 0.007 & 0.005 & 0.002 \\
\hline$R^{2}$ & 0.989 & 0.998 & 0.989 & 0.999 \\
\hline \multicolumn{5}{|l|}{ Thermodynamic parameters } \\
\hline $\mathrm{T}\left({ }^{\circ} \mathrm{C}\right)$ & 31 & 36 & 41 & 46 \\
\hline$\Delta \mathrm{G}(\mathrm{kJ} / \mathrm{mol})$ & -32.71 & -34.56 & -35.89 & -39.79 \\
\hline$\Delta \mathrm{H}(\mathrm{kJ} / \mathrm{mol})$ & \multicolumn{4}{|c|}{104.39} \\
\hline$\Delta \mathrm{S}(\mathrm{J} / \mathrm{K} \mathrm{mol})$ & \multicolumn{4}{|c|}{449.85} \\
\hline$R^{2}$ & \multicolumn{4}{|c|}{0.904} \\
\hline
\end{tabular}
thermodynamic parameters for the adsorption of dye RBV onto chitosan in aqueous solution at $\mathrm{pH} 4$ 
Table 4

Relation between value of $\mathrm{R}_{\mathrm{L}}$ and type of adsorption

\begin{tabular}{lc}
\hline Value of $\mathrm{R}_{\mathrm{L}}$ & Type of adsorption \\
\hline $\mathrm{R}_{\mathrm{L}}>1.0$ & Unfavorable \\
$\mathrm{R}_{\mathrm{L}}=1.0$ & Linear \\
$0<\mathrm{R}_{\mathrm{L}}<1.0$ & Favorable \\
$\mathrm{R}_{\mathrm{L}}=0$ & Irreversible \\
\hline
\end{tabular}

From the results shown in Table 3, the capacities of chitosan for dye adsorption are dependent on the solution temperatures. The values of $\mathrm{a}_{\mathrm{L}}$ and $K_{\mathrm{L}}$ increased when the solution temperature was increased from 31 to $46{ }^{\circ} \mathrm{C}$. These results also suggest that the chitosan-RBV interaction must be an endothermic process.

The basic features of the Langmuir isotherm can be stated in terms of the dimensionless constant separation factor $\left(\mathrm{R}_{\mathrm{L}}\right),{ }^{40}$ which is defined as Equation (21):

$$
R_{L}=\frac{1}{\left(1+a_{L} C_{0}\right)}
$$

where $a_{L}$ is the Langmuir equilibrium constant and $C_{0}$ is the highest initial dye concentration ( $\mu \mathrm{mol} / \mathrm{L}$ ). According to the value of $R_{\mathrm{L}}$, the isotherm shape may be interpreted as described in Table 4 . The values of $R_{\mathrm{L}}$ were calculated to be in the range between 0 and 1 at 31,36, 41 and 46 ${ }^{\circ} \mathrm{C}$, respectively, which indicates that the adsorption is favorable at all the temperatures.

Moreover, in an effort to understand the equilibrium processes involved in RBV adsorption onto chitosan 10B, a computer simulation of the adsorption isotherms has been performed numerically on the basis of the Langmuir model in Equation (19) and using the Langmuir isotherm constants listed in Table 3, and the results were compared with the experimental data (Fig. 7). The observed curves were obtained from the plots of equilibrium adsorption, $q_{\mathrm{e}}(\mu \mathrm{mol} / \mathrm{g})$, versus the liquid phase RBV equilibrium concentration, $C_{\mathrm{e}}(\mu \mathrm{mol} / \mathrm{L})$, at different temperatures. The simulated curves (all the solid lines) were obtained as described. The observed data are well reproduced in the simulated data, as shown in Figure 7, supporting that all the isotherm data are described well by the Langmuir equation. A comparison of maximum RBV dye adsorption onto various adsorbents reported in the literature ${ }^{41-44}$ is shown in Table 5 . Chitosan 10B is found to be an efficient and promising adsorbent to remove RBV from aqueous solution.

\section{Reuse of chitosan}

The typical phenomena of RBV dye adsorptiondesorption-adsorption onto chitosan 10B flakes in aqueous solution are shown in Figure 8. In the adsorption step, the initial dye concentration was $100 \mu \mathrm{mol} / \mathrm{L}$, with a solution $\mathrm{pH} 4.0$ and a temperature of $31{ }^{\circ} \mathrm{C}$, whereas the release of RBV from the dye-loaded chitosan 10B was carried out in $0.1 \mathrm{M} \mathrm{NaOH}$ solution at $\mathrm{pH} 12.5$ and temperature of $31{ }^{\circ} \mathrm{C}$. It was observed that the amount of equilibrium dye adsorption was 58.25 $\mu \mathrm{mol} / \mathrm{g}$ in the first adsorption step, which was maintained for $120 \mathrm{~min}$. The dye desorption rate was rapid for the first $30 \mathrm{~min}$ and $73 \%$ of RBV dye was released from the dye-loaded chitosan within $40 \mathrm{~min}$. After $120 \mathrm{~min}$ of desorption, $90 \%$ of the dye was liberated from the RBV-loaded chitosan. This may be due to the fact that in a basic solution, the positively charged amino groups of chitosan $8 \mathrm{~B}$ are deprotonated, and the electrostatic interaction between chitosan and dye molecules becomes much weaker. ${ }^{22}$ Following the desorption step, the second adsorption step took place and it repeated the similar dynamical shape of the first adsorption step. It takes $120 \mathrm{~min}$ to adsorb a similar amount of RBV dye to that of desorption, and the total amount of dye adsorption is similar to that of the first adsorption step. These results show that our chitosan flakes can be reused for further dye adsorption.

\section{Thermodynamics}

The thermodynamic parameters, such as changes in free energy $(\Delta \mathrm{G})$, enthalpy $(\Delta \mathrm{H})$ and entropy $(\Delta S)$, were determined using the following equations: ${ }^{23}$

$$
\begin{aligned}
& \Delta G=-R T \ln a_{L} \\
& \ln a_{L}=\frac{\Delta S}{R}-\frac{\Delta H}{R T}
\end{aligned}
$$

where $a_{L}(\mathrm{~L} / \mathrm{mol})$ is the equilibrium constant in Table $3, T$ is the solution temperature $(\mathrm{K})$, and $R$ is the gas constant $(8.314 \mathrm{~J} / \mathrm{mol} \mathrm{K}) . \Delta H$ and $\Delta S$ were calculated from the slope and $y$-intercept of 


\section{SUBARNA KARMAKER et al.}

van't Hoff plot of $\ln \mathrm{a}_{\mathrm{L}}$ versus $1 / \mathrm{T}$ (correlation coefficient $\left.R^{2}=0.904\right)$. The results are presented in Table 3. The change in enthalpy $(\Delta H)$ for the adsorption of RBV onto chitosan $10 \mathrm{~B}$ in aqueous solution was estimated to be $104.39 \mathrm{~kJ} / \mathrm{mol}$. The positive value of $\Delta \mathrm{H}$ suggests that the adsorption of RBV by chitosan $10 \mathrm{~B}$ is endothermic, which is supported by the increasing adsorption of RBV with the increase in temperature, while a negative value of $\Delta \mathrm{G}$ and a positive value of $\Delta \mathrm{S}$ indicate that the adsorption reaction is a spontaneous process and more favorable at high temperature. ${ }^{22}$ Generally, the absolute magnitude of the change in free energy for physical adsorption is smaller than that of chemisorption.

Table 5

A comparison of maximum RBV dye adsorption onto various adsorbents

\begin{tabular}{lcccc}
\hline Adsorbent & $\begin{array}{c}\text { Temperature } \\
\left({ }^{\circ} \mathrm{C}\right)\end{array}$ & $\mathrm{pH}$ & $\begin{array}{c}q_{\mathrm{m}} \\
(\mu \mathrm{mol} / \mathrm{g})\end{array}$ & References \\
\hline Chitosan 10B & 31 & 4 & 117.65 & This work \\
Granular activated carbon (GAC) & 70 & 2.5 & 18.49 & 41 \\
Chitin & 70 & 2.5 & 51.93 & 41 \\
Radish leaves (RL) & 70 & 2.5 & 54.38 & 41 \\
Crosslinked poly(N-vinylpyrolidone) (CPVP) & 25 & & 0.14 & 42 \\
Natural rice hull (RHI) & 10 & 2 & 96.74 & 43 \\
Treated rice hull (RHT) & 55 & 2 & 92.27 & 43 \\
Cocoa pod husk & - & - & 49.21 & 44 \\
\hline
\end{tabular}

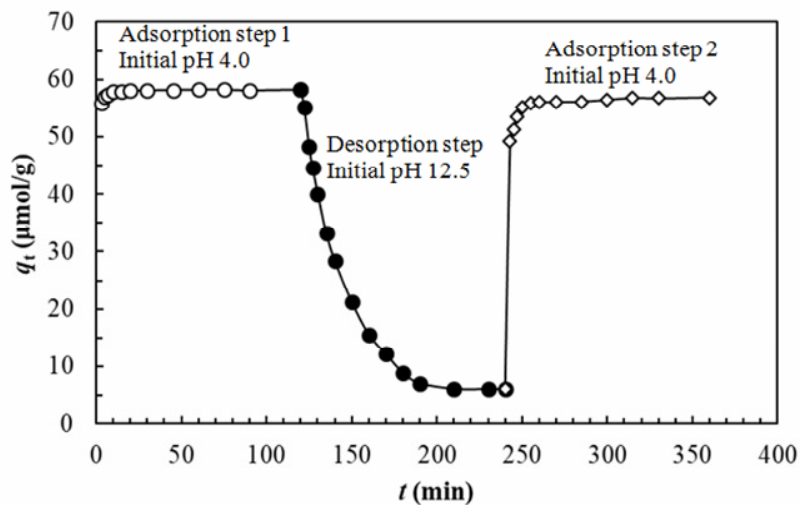

Figure 8: Adsorption and desorption kinetics of RBV on chitosan 10B in aqueous solution at $31{ }^{\circ} \mathrm{C}$ and $100 \mu \mathrm{mol} / \mathrm{L}$ initial dye concentration in three steps: adsorption step 1 at initial $\mathrm{pH} 4.0$, desorption step at initial $\mathrm{pH} 12.5$, and adsorption step 2 at initial $\mathrm{pH} 4.0$

The former ranges from -20 to $0 \mathrm{~kJ} / \mathrm{mol}$, and the latter ranges from -80 to $-400 \mathrm{~kJ} / \mathrm{mol}^{22}$ When the temperature was increased from 31 to $46{ }^{\circ} \mathrm{C}$, $\Delta \mathrm{G}$ increased from -32.71 to $-39.79 \mathrm{~kJ} / \mathrm{mol}$. This could be considered as physical adsorption and more favorable at high temperature, which is supported by the small value of $E_{a}(25.52 \mathrm{~kJ} / \mathrm{mol})$ for the adsorption of RBV onto chitosan 10B. In addition, the considerably low $\Delta \mathrm{G}$ values illustrate saturation in the adsorption process. ${ }^{45} \mathrm{In}$ 2010, Nawi et al. also reported a similar observation for the adsorption of Reactive Red 4 by immobilized chitosan on glass plates. ${ }^{46}$

\section{CONCLUSION}

The adsorption of RBV onto chitosan 10B flakes in aqueous solution was systematically investigated under various conditions. Batch adsorption experiments proved that the solution $\mathrm{pH}$, initial concentration of the dye solutions, ionic strengths and solution temperature significantly influence the initial sorption rate and the amount of equilibrium RBV dye adsorption onto chitosan 10B flakes. The adsorption kinetics could be explained adequately by the pseudosecond-order model, while intraparticle diffusion played an important role in the rate-limiting step. 
The experimental sorption kinetic profiles were perfectly reproduced in the simulated data obtained from numerical analysis on the basis of the pseudo-second-order kinetic model in Equation (4), using the values of $k_{2}$ and $q_{\text {e(cal) }}$ listed in Table 2. Equilibrium adsorption isotherms correlated reasonably well with the Langmuir model, compared to the Freundlich, Temkin and Dubinin-Radushkevich models. Thermodynamic analyses indicated that the adsorption of RBV onto chitosan 10B flakes was endothermic and spontaneous, additionally, the adsorption of RBV onto chitosan 10B flakes was produced via a physisorption process.

A significant amount $(90 \%)$ of RBV dye was released from the dye-loaded chitosan in $0.1 \mathrm{M}$ $\mathrm{NaOH}$ solution $(\mathrm{pH} 12.5)$ and the chitosan flakes could be reused. This study concludes that the readily available chitosan $10 \mathrm{~B}$ could be used as an appropriate adsorbent for removing reactive dyes from wastewater.

ACKNOWLEDGEMENTS: The authors have declared no conflict of interest. This study was financially supported by a special research grant (FY 2013-2014) to Prof. Tapan Kumar Saha from the Ministry of Science and Technology, Government of the People's Republic of Bangladesh. We are grateful to Prof. Yoshinobu Fukumori and Prof. Hideki Ichikawa (Kobe Gakuin University, Kobe, Japan) for providing the sample of chitosan $10 \mathrm{~B}$ and measuring its particle size.

\section{REFERENCES}

1 E. Eren, Clean: Soil Air Water, 38, 758 (2010), https://doi.org/10.1002/clen.201000060

2 S. Chatterjee, S. Chatterjee, B. P. Chatterjee and A. K. Guha, Colloid. Surf. A., 299, 146 (2007), https://doi.org/10.1016/j.colsurfa.2006.11.036

3 M. S. Chiou and H. Y. Li, Chemosphere, 50, 1095 (2003), https://doi.org/10.1016/S0045-6535(02)006367

4 B. Armagan, M. Turan and M. Celik, Desalination, 170 , 33

(2004),

https://doi.org/10.1016/j.desal.2004.02.091

5 T. S. Anirudhan and M. Ramachandran, J. Colloid Interface Sci., 299, $116 \quad$ (2006), https://doi.org/10.1016/j.jcis.2006.01.056

6 T. Ngulube, J. R. Gumbo, V. Masindi and A. Maity, J. Environ. Manag., 191, 35 (2017), https://doi.org/10.1016/j.jenvman.2016.12.031

7 G. Vijayakumar, M. Dharmendrirakumar, S. Renganathan, S. Sivanesan, G. Baskar et al., Clean: Soil Air Water, 37, 355 (2009), http://doi.org. 10.1002/clen.200800228

8 A. Khaled, A. El-Nemr, A. El-Sikaily and O. Abdelwahab, Desalination, 238, $210 \quad$ (2009), https://doi.org/10.1016/j.desal.2008.02.014

9 W. M. A. El-Rahim, O. A. M. El-Ardy and F. H. A. Mohammad, Desalination, 249, 1206 (2009), https://doi.org/10.1016/j.desal.2009.06.037

10 N. Kannan and M. M. Sundaram, Dyes Pigments, 51, 25 (2001), https://doi.org/10.1016/S01437208(01)00056-0

11 F. Rozada, L. F. Calvo, A. I. García, J. MartínVillacorta and M. Otero, Bioresour. Technol., 87, 221 (2003), https://doi.org/10.1016/S0960-8524(02)002432

2 B. H. Hameed, A. A. Ahmad and N. Aziz, Desalination, 247, $551 \quad$ (2009), https://doi.org/10.1016/j.desal.2008.08.005

13 E. Caglar, Y. O. Donari, A. Sinag, I. Birogul, S. Bilge et al., Turk. J. Chem., 42, 86 (2018).

14 T. Murugan, A. Ganapathi and R. Valliappan, E. J. Chem., 7, 669 (2010).

15 A. K. Kushwaha, N. Gupta and M. C. Chattopadhyaya, J. Saudi Chem. Soc., 18, 200 (2014), doi: 10.1016/j.jscs.2011.06.011

16 A. A. Inyinbor, F. A. Adekola and G. A. Olatunji, S. Afr. J. Chem., 68, $115 \quad$ (2015), http://dx.doi.org/10.17159/0379-4350/2015/v68a17

17 S. Banerjee and M. C. Chattopadhyaya, Arabian J. Chem., $\quad \mathbf{1 0}, \quad$ S1629 https://doi.org/10.1016/j.arabjc.2013.06.005

18 L. Liu, R. Wang, J. Yu, L. Hu, Z. Wang et al., RSC Adv., 8, 15804 (2018), DOI: 10.1039/C8RA01563E

19 R. Huang, Q. Liu, J. Huo and B. Yang, Arabian J. Chem., $\quad \mathbf{1 0}, \quad 24 \quad$ (2017), https://doi.org/10.1016/j.arabjc.2013.05.017

20 S. Karmaker, T. Sen and T. K. Saha, Polym. Bull., 70, 2047 (2015).

21 M. Ignat, V. Dulman and T. Onofrei, Cellulose Chem. Technol., 46, $357 \quad$ (2012), http://www.cellulosechemtechnol.ro/pdf/CCT56(2012)/p.357-367.pdf

22 T. K. Saha, N. C. Bhoumik, S. Karmaker, M. G. Ahmed, H. Ichikawa et al., Clean: Soil Air Water, 39, 984 (2011), DOI: 10.1002/clen.201000315

23 W. H. Cheung, Y. S. Szeto and G. McKay, Bioresour. Technol., 98, $2897 \quad$ (2007), https://doi.org/10.1016/j.biortech.2006.09.045

24 H. Ansari, M. Miralinaghi and F. Azizinezhad, Cellulose Chem. Technol., 52, 191 (2019), http://www.cellulosechemtechnol.ro/pdf/CCT12(2019)/p.191-204.pdf

${ }^{25}$ K. Gul, S. Sohni, M. Waqar, F. Ahmad, N. A. N. Norulaini et al., Carbohyd. Polym., 152, 520 (2016), https://doi.org/10.1016/j.carbpol.2016.06.045

26 J. O. Goncalves, J. P. Santos, E. C. Rios, M. M. Crispim, G. L. Dotto et al., J. Mol. Liq., 225, 265 (2017), https://doi.org/10.1016/j.molliq.2016.11.067

27 M. Khan and A. K. M. A. Nowsad, J. Bangladesh Agric. Univ., $10, \quad 367 \quad$ (2012), 
https://doi.org/10.3329/jbau.v10i2.14930

28 S. Lagergren, K. Sven. Vetenskapsakad. Handl., 24, 1 (1898)

29 G. McKay and Y. S. Ho, Process Biochem., 34, $451 \quad$ (1999), https://doi.org/10.1016/S00329592(98)00112-5

30 S. Y. Elovich and O. G. Larinov, Izv. Akad. Nauk SSSR, Otd. Khim. Nauk, 2, 209 (1962).

31 W. J. Weber, J. C. Morris and J. Sanit, J. Sanit. Eng. Div., Proc. Am. Soc. Civ. Eng., 89, 31 (1963).

32 H. Freundlich, Z. Phys. Chem., 57, 384 (1906).

33 M. I. Temkin and V. Pyzhev, Acta Physiochim., 12, 327 (1940).

34 A. A. Inyinbor, F. A. Adekola and G. A. Olatunji, Water Resour. Ind., 15, $14 \quad$ (2016), https://doi.org/10.1016/j.wri.2016.06.001

35 I. Langmuir, J. Am. Chem. Soc., 40, 1361 (1918), https://doi.org/10.1021/ja02242a004

G. McKay, H. S. Blair and J. R. Gardner, J. Appl.

Polym. Sci., 27, 3043 (1982),

https://doi.org/10.1002/app.1982.070270827

36 A. H. Chen, S. C. Liu, C. Y. Chen and C. Y. Chen, J. Hazard. Mater., 154, $184 \quad$ (2008), https://doi.org/10.1016/j.jhazmat.2007.10.009

37 A. H. Chen, C. Y. Yang, C. Y. Chen, C. Y. Chen and C. W. Chen, J. Hazard. Mater., 163, 1068 (2009), https://doi.org/10.1016/j.jhazmat.2008.07.073

38 Y. C. Wong, Y. S. Szeto, W. H. Cheung and G. McKay, Langmuir, 19, $7888 \quad$ (2003), https://doi.org/10.1021/la030064y
39 K. R. Hall, L. C. Eagleton, A. Acrivers and T. Vermenlem, Ind. Eng. Chem. Fundam., 5, 212 (1966).

40 R. Sanghi and B. Bhattacharya, J. Sci. Ind. Res., 61, 432 (2002), http://hdl.handle.net/123456789/26358

41 S. Ekici, Y. Isikver, N. Sahiner and D. Saraydin, Adsorpt. Sci. Technol., 21, $651 \quad$ (2003), https://doi.org/10.1260/026361703772776439

42 G. A. C. Ribeiro, D. S. A. Silva, C. C. dos Santos, A. P. Vieira, C. W. B. Bezerra et al., Polimeros, 27, 16 (2017).

${ }^{43}$ O. S. Bello, T. T. Siang and M. A. Ahmad, Asia-

$\begin{array}{lllll}\text { Pac. J. Chem. Eng., 7, } 378 \text { (2012), } & \end{array}$ https://doi.org/10.1002/apj.557

44 S. Chatterjee, S. Chatterjee, B. P. Chatterjee, A. R. Das and A. K. Guha, J. Colloid Interfac. Sci., 288, 30 (2005), https://doi.org/10.1016/j.jcis.2005.02.055

45 M. A. Nawi, S. Sabar, A. H. Jawad, Sheilatina and W. S. W. Ngah, Biochem. Eng. J., 49, 317 (2010), https://doi.org/10.1016/j.bej.2010.01.006 